\title{
The Strategy of Indonesian Local Press to Face the Effect of Covid-19 Global Pandemic
}

\author{
Anas Syahirul Alim ${ }^{1 *}$ Sri Hastjarjo ${ }^{2}$ Andre N. Rahmanto ${ }^{3}$ \\ ${ }^{1,2,3}$ Faculty of Social and Political Sciences, Universitas Sebelas Maret, Surakarta, Indonesia \\ "Corresponding author. Email: anassyahirul@gmail.com
}

\begin{abstract}
The Covid-19 global pandemic affected all sectors of life, including the press. The function of the press as a provider of information is disrupted. Print media is the most affected. There is a press publishing company that has production functions. There are also those who survive with difficulty. Many problems faced by the local press in Indonesia during the Covid-19 pandemic are described in this paper. This paper uses Media Economic Theory to analyze and uses qualitative methods to collect data about press in Indonesia during Covid-19 pandemic. The discussion shows how Indonesian local press must be creative to manage human resources and make some efficiency programs to survive. This paper contributes to research about media and Covid-19 global pandemic as novelty.
\end{abstract}

Keywords: Indonesian press, global pandemic, covid-19

\section{INTRODUCTION}

Press or media, exists as an institution that has idealism to educate society and also as social control. The mass media or the press plays an important role in the era of democracy. The press is a medium for people's expression, a communication bridge and of course the press is a means of monitoring the people in the life of society, nation and state. The function of the press in a country is important to the formation of a democratic society in a country. For this reason, the press has an important function for the development of a country towards the life of a democratic nation and state.

Due to Indonesian Law, Undang-Undang No 40/1999 regulates the role of the press, namely:

1). Fulfilling the public's right to know information.

2). Upholding the basic values of democracy.

3). Encouraging the realization of the rule of law and human rights.

4). Respecting diversity.

5). Developing public opinion.

6). Supervising, criticizing, correcting and suggesting.

7). Fighting for justice and truth. [1]

This law also regulates the function of the press, namely as media of information, education, entertainment and social control as well as functioning as an economic institution. According to Widodo (1997) [2], there are many functions of the press in society, namely:

1). To inform, the press has a function to provide information or news to the public or readers, through writing, broadcasts and regular broadcasts to the press, providing various kinds of information.

2). To Educate. The press functions as an educator, through the various kinds of writings or messages it gives, the press can educate the reading public.

3 ). To Control. The press in the midst of society plays a role in providing social control through criticism and constructive input. Reporting of irregularities and acts of violating regulations committed by some groups of people or officials is a form of contribution in controlling society and government officials.

4). To Bridge. The press has a function as a liaison or bridge between society and the government or vice versa. Aspirations that cannot be channeled through existing channels or institutions can be conveyed through the press.

5). To Entertain. The press can provide entertainment to the public, entertaining here is not only in the sense of funny things but can be in the form of satisfaction and enjoyment of the press.

The press is needed according to its function, whether for individuals, organizations, institutions or institutions, not only to obtain information but more than that because the press can shape public opinion. The press can become a facilitator, liaison, catalyst and interpreter to become a dialogue forum between the government (officials) and the people. Likewise, the press can create a crisis, as well as create awareness in society. Some others add that the function of the press is a function of influence (to influence) which causes the press to play an important role in people's lives. The function of influencing the 
newspapers is implicitly contained in the editorial and articles.

The critical function of the press is also accepted by democratic societies. In Indonesia, after the New Order, it was well-established that the press has played a major role in guarding Indonesia's democratization which has been rolling rapidly until now. Based on that, the Indonesian press truly deserves the title of being the fourth pillar of democracy.

From this description, it can be concluded that there are enormous benefits to the presence of the press / media in a society, especially in a democratic society. That is the role and function of the idealist press / media in the community.

On the other side of the idealist role and function, the press is also confronted with the role of the economy, namely to play a role as a gainer of business profits. The press / media also move with a business orientation to support the activities of the press company organization. This economic role will also have an impact on the role and function of the idealism of the press. In order for the role and function of idealism to run well, of course it must be supported by good conditions in the media economy. If the economy of the media / press company is good, then the press can also play its idealistic role well. On the other hand, if the economy of the media / press company experiences a disturbance or a downturn, the role of the idealism of the press will not run optimally.

The media economy or press institution business will experience contraction when the economy of a country or region experiences problems. As is currently happening throughout the world, including Indonesia, with the Covid19 pandemic, it also has had an impact on economic sustainability.

The Covid-19 pandemic has affected all sectors of the economy at the global level, including throughout Indonesia. The health crisis due to the presence of the corona virus has led to an economic crisis. Almost all business entities have experienced a downturn due to the Covid-19 pandemic, including the media business sector. As a business institute, the media are also heavily impacted so that it has an immediate impact on the running of the media organization, both national and regional media.

One month since Indonesia was first declared infected with the corona virus and the existence of restrictions on the mobility of its citizens, almost the media experienced a contraction in terms of business ventures and editorial performance in carrying out the mission of idealism of the press. The economic impact of the media continues and worsens along with the increasing health crisis due to the corona virus in Indonesia.

During the pandemic, especially in early months, the space for the media business was limited. The press / media have difficulty getting advertisements which are the main income for a media institution in supporting the running of the media organization. The press / media also find it difficult to hold various profitable events. As a result of the pandemic, press / media institutions have had difficulty accessing other potential business benefits.
Meanwhile, production costs tend to increase, such as the price of a number of materials for printed media which are affected by the impact of the rupiah against the US dollar. Print media managers are hesitant to market. Printed newspapers are difficult to sell because the priority of people's needs during a pandemic is to target the most basic aspects of life's needs, namely food and health. At the time of the policy of restricting the movement of society, the print newspaper business experienced the most difficult times because there was no retail purchase of newspapers. Newspaper marketers are also nervous when the burden of printing production costs has also increased, while the price of newspapers cannot be increased.

The breath of the media in Indonesia, especially print media, has been getting tighter and tighter since the arrival of the corona pandemic. Not only did the number of subscribers continue to decline, the sales of advertisements that became his life support were also starting to drag. The drop in revenue from advertising immediately drained the financial foundation, especially newspaper publishers, most of which had already applied subsidies to their newspaper subscribers. Meanwhile, the operational costs are not reduced but also increased. The decline in newspaper advertising revenue not only cuts profit potential, but directly affects the smooth running of production and reduces the quality of journalistic work.

Other media platforms, electronic and online (digital) have also experienced a similar fate. Advertising fell sharply, operations swelled. Moreover, media that are joined in one convergence, which currently manage print, electronic (television, radio) to online.

There have been calls from media companies, journalists' associations and also the Press Council for the government to help the mass media survive the Covid-19 pandemic. So, various formulas emerged to help the conditions of the media industry, starting from the elimination of taxes, paper subsidies, subsidizing the selling price of newspapers, easing the electricity burden, easing the tax burden, delaying the payment of BPJS dues to the JPS discourse for media crews.

The deteriorating condition of the media is not only experienced by the media in the country, but also affects media entities in almost all countries. In Australia, Rupert Murdoch's flagship Australian media group, News Corp, has announced it is stopping the print edition of some 60 regional newspapers. This was done because the problematic sector received a new blow from the decline in advertising during the corona virus pandemic. News Corp said newspapers in the states of New South Wales, Victoria, Queensland and South Australia would discontinue print editions and go online. The coronavirus crisis has created unprecedented economic pressure and they must be able to retain as many workers as possible.[3]

The media in the regions are really confused about the impact of this corona pandemic. Until the three months of Coronavirus running, there was almost no policy of concern aimed at the press in Indonesia. So, they also have to struggle independently with their respective strategies in order to survive.

The disruption of the media economy will 
undoubtedly disrupt the operational performance of the press in playing its role in society ideally. That is why the press must get attention and assistance from the government during the Covid-19 pandemic. The goal is to enable the media / press to carry out the role and function of idealism continuously in society, so that public rights to be obtained from the press / media can be fulfilled.

1. The media have a strategic role in society. Mainstream media is an important force in guarding the tasks of government and society. The media also plays the role of humanity, the role of education and information. Without the presence of the media, there is no balance for the government and society. The media also clarifies misinformation that has emerged in the community, for example those related to the pandemic. In the midst of misinformation that has emerged in society both in the form of narratives and memes, it is necessary to have a media that continues to provide it correctly. The press serves as a balancing force, the power of education and the spreader of correct information. Especially during the Covid-19 pandemic, the presence of the press was needed. They provide development information about Covid-19 every second so that the public has the right news about the outbreak. Then the press also educates the ins and outs of Covid-19 so that the public becomes more knowledgeable, and the press will also control policies that are not pro-society.

2. The presence of the Covid-19 pandemic has destroyed the existence of the media and threatens the important role of the press in this society. The media also does not feel the government's concern in overcoming these media problems. So what the media is doing is trying hard to survive with their respective strategies so that they can play an important task for society.

3. The conditions of the Covid-19 outbreak have hit the press in the regions badly. Each press company has its own strategies so that they can survive the impact of the economic crisis due to the corona pandemic.

\section{LITERATURE REVIEW}

The press or mass media is no longer just a social institution. The paradigm of the press as a social institution is an old perspective whose orientation is only as a means of struggle through the work of journalistic products (writing). However, in its development the media has become a business entity. Especially in the era of advances in communication and information technology, the media has become an extraordinary industry. The media business competition is getting more competitive.So a new study emerged in the field of communication, namely Media Economics. This science combines two studies: media studies and economic studies. Mass media is an economic institution that is concerned with the production and causes of media content targeted at audiences or consumers [4].

Media is a business institution that produces and disseminates knowledge, education, and entertainment information to target consumers. Because the media is an economic entity, its behavior is influenced by the economy [5].

Hopkins; et al (2004), Hiebert, et al (1991), McQuaill (1992) and Albarran (1996) suggest three analytical frameworks that can explain the various facets of media business work. At the same time, these three frameworks are quite relevant indicators for assessing the characteristics of the media industry because they provide basic information related to the uniqueness of mass media business operations. The three analytical frameworks referred to include economic structure, company operation and company performance [6].

But in contemporary times, press companies are no longer just selling or marketing their content products to the market (audiences). But the media are also required to be more creative in selling other potential products such as advertisements, events, research and others. For the media industry, most of the revenue still comes from advertising. Admittedly, the media business has a different character than other businesses. So there is a separate study on Media Economics. In the media business, there are other things that other businesses do not have.

There are three things that distinguish the media industry from other industries: (1) in the media industry, the role of advertising is very dominant, (2) mass media for the public (citizens) is an important source of information, and (3) unlike other industries, the media industry is an industry protected by the country's constitution [7].

In addition, what distinguishes the media industry from other industries is its economic characteristics, such as: (1) dual product, namely: product content and audience product, (2) dual market, namely: consumer market and advertiser market, and (3) the media industry has dual missions, namely: economic and non-economic or public missions. The above characteristics are sufficient to make the problem of managing media companies more complicated than other industries. On top of these characteristics, the media industry still has characteristics inherent in its cost behavior, such as: (1) economies of scale, (2) economies of scope, savings on integration (economies of integration).

The three types of savings can be achieved by the media industry if the amount of production is large; the products can be varied and can even be a combination of various businesses. Because of this cost characteristic, the larger the newspaper circulation, the cheaper will be the price charged to consumers; On the other hand, the income from advertising will increase, because audience products will be more attractive to advertisers. The possibility of increasing the amount of lint is due to the attractiveness of the quality of the newspaper content [8].

Information is the main business of the media industry; then content is the core business (core business). That is, content is everything for those who want to manage media successfully.7 Only those who are aware of this will succeed from their media business. This applies to print media, online media and electronic media (radio or television). So maybe the motto in the media industry is: 
content, content and content. Good content will bring in readers / listeners / viewers or audiences. A large audience will certainly generate income in the media business. Whether in the form of advertising, content sales, viewers and so on.

Advertising still dominates revenue in the media business. When advertisements for media are removed from company/institutional/individual budgets due to the economic crisis due to the Covid-19 pandemic, it is certain that the media will be confused. It is because in Indonesia, the income for the mass media comes from advertising. Just like other business structures, the media business will also be influenced by the situation and conditions that are happening in society. When the economic conditions in Indonesia and the world are being hit by an economic crisis due to the impact of the Covid-19 health crisis, it will directly impact the media industry, as a business entity.

The economic structure of the entire society is influenced by political, legal and social characteristics that shape the business practices or activities of media companies. Then the logical implications of media globalization are that the media are managed with a modern management system, media industrialization, media economization; both in the local, national and especially in the global-international media industry [9].

\section{METHODS}

The method used in this research is qualitative. Researchers conducted observation and exploration with case studies of the economic impact experienced by the press industry due to the Covid-19 pandemic. Case studies are used to examine the results of observations made on the economic impact of the local press and the strategies adopted. Researchers interacted with documented data materials and conducted in-depth interviews with specific statements.

Exploratory research is a type of research aiming to explore or to seek problems in order to gain insight and understanding. Exploratory research can formulate problems or define problems more precisely, identify alternative courses of action, develop hypotheses, separate variables and relationships for further testing, gain insight to develop approaches to problems, and make priorities for further research [10].

Researchers use in-depth interview techniques to collect data. In-depth interviews are a way of collecting data or information by directly interacting with informants in order to obtain complete and in-depth data. This interview was conducted intensively [11]. Thus, the desired data will be obtained and can be a competent source for this research. In this in-depth interview the researcher would try to take on the role of the party being studied, to dive intimately into their psychological and social world. In order to achieve their goals, the interviewer encouraged the interviewed party in various ways to express all their ideas and feelings freely and comfortably [12].
The object of this research was media published from various regions in Indonesia, the samples of which were taken randomly. The media used as the object of research comes from various media platforms from print, electronic to online.

\section{RESULTS AND DISCUSSIONS}

All media/press businesses have almost been hit by the economic crisis caused by Covid-19. The presence of the corona virus not only causes a health crisis but also directly impacts the economic crisis. The existence of restrictions on the mobilization of citizens is the most influencing factor in the stagnation of the business world, including business in the media sector. If the media business is disrupted, then the press cannot perform its role properly. So the loser is the community.

The economic impact experienced by press companies, especially regional press during the Covid-19 pandemic, was very pronounced. There are those who simply experience a decrease in turnover until a number of media have dismissed their employees.

Through this study and research, we want to find out what strategies the regional press carried out during covid19 and the recovery period or after covid-19 to stay afloat.

In a survey conducted by the Media Companies Union (SPS) during the Pandemic early 2020, it was stated that the impact experienced by these media companies was almost evenly distributed across all media platforms. The survey entitled "The Face of a Print Press Company during the Covid-19 Pandemic" states the following:

1. All print media cuts the page count, starting from national to regional newspapers.

2. A number of online media have conducted Mass Termination of Employment (PHK).

3. The majority (71 percent) of press companies fell in turnover of more than 40 percent

4. A number of media have experienced a drastic drop in turnover of up to 80 percent

5. Regional press companies are under much greater pressure than press companies based in Jakarta

In the Forum Group Discussion (FGD) held by the Central Indonesian Journalists Association (PWI) with participants from representatives of PWI management in all regions, similar aspirations were also obtained, that is, media managers in the regions experience financial difficulties to support the operational financing of their media activities.

Responding to the Covid-19 pandemic which has an impact on the condition of the press / media, Central PWI has specifically held two FGDs attended by regional PWI administrators. The first FGD discussed specifically the impact of the Covid-19 pandemic from the economic/business side which took place on April 21, 2020 via online using the zoom application. On that occasion, his tone was almost the same that Covid-19 had hit the media economy in almost all media in the regions. The only difference is the level of impact that is felt, the programs and strategies that have been implemented to 
stay afloat.

From the FGD, media managers in the regions stated that due to the conditions of the Covid-19 pandemic, regional media must work hard to survive. They are also confused about their daily operations because their income has decreased so drastically.

The condition of the media/press during the Covid19 pandemic experienced almost the same problem. First, market advertising has dropped dramatically. Advertising in all media has decreased. Product and service owners experience economic problems so that the budget for promotion through advertising is cut or even eliminated.

Advertising revenue fell by $30-40$ percent. The decline in revenue began in March and continued to decline in April- May-June. Second, the media / press have difficulty selling their products, especially print media. Products that have been made are difficult to sell, that's at least because; people's purchasing power has decreased, restrictions on citizens' mobility by the government have affected access to newspaper purchases, fear among some residents of the transmission of the corona virus due to contact with newspaper products. There were also many customer terminations for newspapers and magazines during the pandemic. Third, the media have difficulty accessing information to produce quality and varied coverage. This is due to restrictions on mobility, limited access to sources because only through technology connections which often have the potential to experience complete communication failure either due to network factors or other psychological factors. Fourth, the media/press, especially in the regions, has operational costs that are greater than revenues. Expenditures are greater than income earned. As a result, their cash was eroded, which on average was not small. Moreover, many press companies in the regions do not have large cash reserves or even none at all. Many small media in the area have their cash flow run out only once per month without leaving cash in the following month (results of interviews with a number of media managers in the regions). The character of the media in areas that are highly dependent on advertisements, both government and private advertisements, will be increasingly vulnerable to economic crises such as during the Covid-19 pandemic. If there is an economic crisis, the budget allocation for advertising/promotion in the media becomes one of the budgets that the institution will cut for the first time. As in the economic crisis due to this pandemic, government agencies as well as many private institutions (companies, universities and others) have immediately cut costs for media advertising/promotion. The media/press will automatically be affected because of their heavy dependence on advertising revenue. Actually there is a paradox experienced by the mass media of this pandemic. With the exception of print, all types of media experience increased traffic for the number of consumers. For example, online media has seen an increase in viewership during this pandemic. Radio media has increased the number of listeners and television has increased the number of viewers, except for print media, which in fact has decreased in readership. The increase in the amount of consumer traffic experienced by online media, radio and television is understandable considering that residents need information, especially regarding Covid-19 and the existence of a policy to restrict mobilization so that residents have to stay at home. Then access to media consumption increases. It's just that, despite experiencing an increase in consumer traffic it doesn't have a significant impact on ad revenue. Increase in consumer traffic by up to 50-60 percent. The increase in consumer traffic occurred on April and high on May 2020. On the other hand, there was a decrease in advertising revenue which reached 30-40 percent. The decline in advertising revenue began on March and continued to decline from April to May-June.

So what are the strategies that have been carried out by regional media managers in facing the economic crisis due to the Covid-19 pandemic? From the results of observations and interviews with media managers, it was found that there were a number of steps or programs carried out by media managers in the regions so that they could survive during the economic crisis, including:

\section{Payroll deductions}

Most of the media in the regions must reduce the amount of salaries of their employees/employees. The average has started in April 2020, and stepping on the month of May more media have to reduce the salary/honorarium of their employees. This policy of cutting wages is not only experienced by the regional press but also the national press. Several electronic and online media in Central Java stated that they had reduced the salaries of reporters, broadcasters and other employees. Meanwhile, AMSI Indonesia stated that about 20 percent of its 319 members had already cut employee salaries including the editorial team. The amount of deductions in salary / honorarium varies. Some are deducted from 5 to 30 percent of their take home pay received.

\section{Reduction of Hours of Work}

Reducing working hours was also a strategy adopted by the regional press due to the economic crisis. A number of online media in Central Java have gone this way. Its composition includes implementing a reporter picket system. Reporters and editors do not have to produce news every day. They take turns in turn between their editorial teams. There are those who impose reporters and editors into invoices, some are rationed for a month to only enter 15 days or produce news with 15 working days. This policy was also enforced by a number of local television stations in Central Java.

\section{Laying off employees}

There are also regional press companies that have lain off employees. About 15 percent of AMSI members have lain off their employees. This was found in East Java, Riau, NTB, and Southeast Sulawesi (explained by the Head of AMSI). There are about 10 percent of SMSI members who also lay off some of their employees (explained by the Head of SMSI).

4. Reduce Print

Reducing the number of prints is the fastest choice made by print media managers in the regions during the Covid- 
19 pandemic. On average, they immediately cut the number of prints as soon as Covid-19 began to spread. Apart from cutting operational costs, the reduction in printing was also caused by reduced newspaper purchases and the number of subscription terminations.

5. Media Shutdown

The economic crisis due to the Covid-19 pandemic also has had an impact on the closure of the media. Online media has experienced this closure, one of which is online media in East Java (said by the Chairman of AMSI, Wenseslaus Manggut). In some areas, a number of online media are also threatened with closure after being affected by the pandemic. They took this strategy with the hope that after the pandemic they can return to activity.

6. Cancellation of Recruitment for Journalists and Employees

Another strategy carried out by media managers in the regions is canceling the recruitment of new employees from both editorial team and marketing team, as well as other departments. As experienced by one of the media in Solo City which immediately canceled the plan to recruit new reporters once the Covid-19 pandemic was prolonged. The same thing is also experienced by other media in various regions in Indonesia.

\section{Cancellation of Appointment of Permanent Employees}

In addition to canceling the recruitment of new employees, a number of regional media have also implemented a strategy of canceling the appointment of permanent employees for employees who should have been appointed according to schedule. So what is done is to extend the employee's work contract and / or cancel the work contract temporarily. Because if it is appointed, the consequences are usually additional components that must be fulfilled by the company such as BPJS, family allowances, mobile credit and others.

8. Postponement of Salary and THR

Another strategy adopted by regional press companies is to delay payment of salaries for a certain period. For example, a salary that can be received at the beginning of the month is partially given in the middle of the month. There are also those who postpone salary payments with other formulas. There are also press companies that canceled the payment of the Idul Fitri allowance (THR) on May 2020. It is not uncommon for those who pay the THR in installments.

\section{CONCLUSION}

The Covid-19 pandemic has caused an economic crisis in all sectors, including the media/press industry. If the press is disturbed, it will affect the quality of the role and function of the press in society. So in the end, the losers are the people because they do not get optimal, varied and quality information.

The impact of the economic crisis due to this pandemic has eroded cash flow in almost all regional press. Some predict that it will only last 6 months, 7 months to 12 months if conditions do not change. So, concrete strategies must be implemented so that the regional press can survive the economic crisis due to the pandemic. A number of strategies have been taken by local media.

On the other hand, the pandemic forces editors to further adapt to digital culture in obtaining and producing news. This is to get around the WFH obligations, social distancing, and territorial restrictions. Search for news ideas from digital (social media, apps, conversations). Reportage is also done through online platforms such as zoom, google meet and others.

\section{ACKNOWLEDGMENT}

This work was supported by Dewan Pers (Indonesian Press Council) and Persatuan Wartawan Indonesia (PWI), Asosiasi Media Siber Indonesia (AMSI) and Serikat Media Siber Indonesia (MSMI).

\section{REFERENCES}

[1] Undang-Undang No 40 Tahun 1999

[2] Widodo, 1997, Teknik Wartawan Menulis Berita di Surat Kabar dan Majalah, Indah, Ed. I, Surabaya, pp. 7-8

[3] Rita Uli Hutapea, Imbas Pandemi Virus Corona 60 Surat Kabar Australia Berhenti Cetak, Detik.com, 1 April 2020

[4] Picard, Robert G. The Economics and Media Companies. (2002) New York : Fordham University Pers.

[5] Albarran, Alan. 1996. Media Economics: Understanding Markets, Industries, And Concepts. Ames: IOWA State University

[6] Wirth and Bloch, 1998.

[7] Hasan, Bakir, 2005 Ekonomi Media: Perlukah? Jurnal Mediator, Vol 7, No 2, December 2006

[8] Hasan, Bakir, 2005 Ekonomi Media: Perlukah? Jurnal Mediator, Vol 7, No 2, December 2006

[9] Hoskins, Colin; Stuart McFadyen, Adam Finn, 2004. Media Economics: Applying Economics to New and Tradisional Media. London:Sage Publications

[10] Aminah, Ekonomi Media, International Politics Economy Lecture, Jakarta Muhammadiyah University.

[11] Malhotra, N.K.(2005). Review of marketing research Vol.1. M.E.Sharpe.

[12] Mulyana, Deddy, 2004, Metodologi Penelitian Kualitatif, Roesda Karya, pp 183. 